\title{
The Impact of Political Culture on Firms' Choice of Exploitation-Exploration Internationalization Strategy
}

\section{Sungu Armagan}

The University of Utah, USA

\section{Manuel P. Ferreira \\ Escola Superior de Tecnologia e Gestao, Portugal}

\begin{abstract}
This article discusses the impact of political culture on the exploitation-exploration internationalization strategies of firms. In particular, we propose that four dimensions of political culture - nationalism, internationalism, patriotism, and cosmopolitanism - influence firms' willingness to explore new opportunities and/or to exploit existing products and capabilities across borders. We suggest that firms in nationalist home country cultures are more likely to pursue exploitation strategies, whereas those in cosmopolitan cultures are more likely to pursue exploration strategies. For firms embedded in patriotic or internationalist cultures, a mix of exploitation and exploration internationalization strategies might be the more likely choice. We conclude that these political culture dimensions may be useful to understand and predict many firm-level strategic choices, such as the type of internationalization strategy pursued, the choice of foreign entry mode and location, and decisions concerning the management of foreign subsidiaries.
\end{abstract}

KEY WORDS $\bullet$ exploitation $\bullet$ exploration $\bullet$ internationalization strategy $\bullet$ political culture

\section{Introduction}

The strategies firms adopt to enter international markets have been extensively studied in management research. Some examples of international strategic decisions include the selection of entry modes (e.g. strategic alliances, joint ventures, or cross-border acquisitions), whom to hire to manage the subsidiaries abroad (i.e. locals or expatriates), 
and whether to adapt the product portfolio for exports or foreign investment operations. Often, these decisions are driven by assumptions about the host and home country qualities and cultural differences, and influence firms' performance (Calof and Beamish, 1994; Hofstede, 1980, 1991). Miscalculated strategic decisions may create future hazards, lowering the likelihood of survival and success of international operations. Therefore, it is crucial to understand the factors underlying firms' strategic decisions, in particular, aspects of home and host country qualities and conditions that facilitate these decisions.

Despite prolific research on firms' international strategies, which stem from the multiple areas of industrial organization, economics, management, and cross-cultural studies, the area of international management is still ill informed as to the impact of home and host country cultural values on firms' choice of internationalization strategy. Scholars have predominantly utilized Hofstede's (1980) cultural dimensions (collectivism-individualism, uncertainty avoidance, power distance, masculinity-femininity), and, to a lesser degree, Trompenaars and Hampden-Turner's (1998) classification of culture (e.g. universalism vs. particularism, communitarianism vs. individualism, achievement vs. ascription, and the human-time relationship), or Perlmutter's (1969) typology of management approaches (i.e. ethnocentrism, geocentrism, and polycentrism) to examine the impact of culture on firms' strategy (e.g. Hennart and Park, 1993) and performance (e.g. Li et al., 2001). The effect of culture and cultural distance on foreign entry modes (Brouthers and Brouthers, 2000; Kogut and Singh, 1988; Makino and Neupert, 2000), joint ventures' performance (Pothukuchi et al., 2002), performance outcomes in alliance negotiations (Teegen and Doh, 2002), multinational management teams utilized in international joint ventures (Salk and Brannen, 2000), and business failures (Li and Guisinger, 1991) are some of the examples of research on culture and firms' strategy and performance. However, the extant research has not yet examined how home and/or host country political culture may influence firms' internationalization strategy.

The purpose of this paper is to provide a conceptual discussion of the impact of political culture - nationalism, patriotism, internationalism, and cosmopolitanism - on the internationalization strategies pursued by firms. Our examination of political culture represents a significant departure from previous studies that used, for example, Hofstede's (1980) cultural dimensions, while contributing to existing research on the impact of culture on firms' strategies by examining how political culture can affect firms' choice of internationalization strategy. We argue that the political culture of the firms' home country is likely to influence the internationalization strategies firms pursue as well as the modes of foreign market entry and foreign locations.

Political culture represents the political orientations and attitudes toward the political system (Almond and Verba, 1963, 1989). It also entails attitudes and behaviors, some related to individuals' beliefs and values (e.g. suspicion towards foreigners) and some to individuals' behaviors (e.g. extent of political participation, consumption of foreign products), while others are defined at a more macro level (e.g. extent of institutional participation) (Melberg, 1996; White, 1979). While the concept of political culture is considered to have its roots in individuallevel political behaviors, political culture is believed to manifest itself in collective behaviors and formal governmental policies in addition to individual behaviors (see Druckman, 1994 for nationalism). This paper discusses how different political culture environments influence firms' choices of internationalization strategy. The level of analysis that we ascribe to is the political culture of the country in which organizations 
are embedded. We compare organizations in different cultural environments in terms of the types of internationalization strategy they pursue.

We distinguish countries and, hence, the individual decision makers in organizations within these countries based on the average cultural predisposition of the population. Although suffering from limitations, this approach is common in international and cross cultural management studies since belonging to a certain nationality or culture is believed to have a potent influence on individuals' attitudes and behavior (e.g. Hambrick et al., 1998) as well as on their knowledge, assumptions, or perceptions about the world (e.g. Lord and Foti, 1986), even though not all individuals of the same nation or culture will necessarily share the totality of these cultural characteristics. From this perspective, numerous studies have shown that national culture affects management practices and firms' strategies (Hofstede, 1980, 2001; Parkhe, 1991). Similar to this research, we take an aspect of culture, in the present case the political culture of a nation, to infer the tendencies of decision makers in firms embedded in different national environments.

This article is organized into three main sections. In the first section, we provide a review of the core concepts of exploitation and exploration strategies. In the subsequent section, we overview the dimensions of political culture and formulate our main propositions. In the third section, we develop propositions on how an internationalization strategy may reflect on the choice of foreign entry mode and provide examples of firms' strategy aligned with these entry modes. We conclude with a discussion, implications for practitioners, and suggestions for future research.

\section{Exploration and Exploitation Strategies of Firms}

March (1991) suggested a model of exploitation and exploration in organizational learning that stipulates a linkage between the adaptation of firms, the changes at the population (of firms) level and the environment. Each firm strategy such as whether to enter a new market, to cooperate in an alliance, or to form a joint-venture in a foreign country can be seen through the exploitation-exploration dialectic. Exploration is associated with the discovery of new opportunities, search, innovation, building new capabilities, developing new skills and routines, variation, and risk taking (Koza and Lewin, 1998; March, 1991). Firms pursuing an exploration strategy are more prone to assume risk and look for market opportunities beyond the traditional and current pool of markets (Levinthal and March, 1993), most notably beyond their home country markets. Exploration is a process of searching for a peak in a rugged landscape (Levinthal, 1997) and as such is based on trial and error where the benefits are assessed after costs have been incurred. Hence, to succeed firms need to pursue a healthy dose of exploration, possibly through pursuing novel business ideas, utilizing new technologies, and/or entering new geographies.

Exploitation, on the other side, is related to improving the use of existing capabilities, technologies, assets, and products that the firm possesses (March, 1991). An exploitation strategy is almost risk free as the firms essentially replicate in other markets what they know and know to work. Firms find it easier to use an existing set of resources and capabilities, namely knowledge-based capabilities, which they already hold in developing market offerings, than to explore new opportunities. We expect that firms pursuing an exploitation strategy will essentially search market opportunities locally or in familiar markets and/or businesses - that is, in their 
surrounding landscape. However, these firms can only aim at reaching local peaks, but, these peaks are likely to be sub-optimal or local maximums except when the firms find an optimal peak by chance.

Eventually, firms may need to balance the two pressures towards exploitation and exploration to assure current viability as well as to ensure future prospects (March, 1991; Levinthal and March, 1993). Levinthal and March (1993: 105) noted that firms' longterm survival depends on their ability to 'engage in enough exploitation to ensure the organization's current viability and engage in enough exploration to ensure its future viability'. However, while the returns associated with an exploration strategy are distant in time, highly variable, and unpredictable, the returns associated with an exploitation strategy are proximate in time and more certain.

The firms' ability to pursue exploitation and exploration strategies simultaneously is dependent on the stock of knowledge possessed and the ability to acquire new knowledge (Levinthal and March, 1993) which, in turn, requires the firm to be sensitive to local variations. We argue that the extent to which firms are sensitive to local variations and/or engage in search activities is influenced by the political culture of the countries in which they are embedded. This is not to convey that the exogenous elements such as the political culture of the home country should have a determining role on firms' strategies. On the contrary, decision-making and strategizing as a particular form must be dependent on hard evidence, and be pursued with a rational mindset. In familiar environments, a process of replication (Nelson and Winter, 1982) of what worked well in the past or in other environments may suffice. Conversely, in unfamiliar environments replication may not suffice and active strategies with probable assumption of risk are called upon.

While strategic management research has searched for firms' rational decision-making procedures, formal strategizing mechanisms, intelligent search, and selection criteria on which to support strategies and allocate resources, individuals' bounded rationality constraints limit these processes (Simon, 1957). Thus, factors such as the political culture environment of the firms' home country may influence the strategic decisions such that the decisions may be made in a suboptimally rational manner because managers do not attend exclusively to efficiency or effectiveness criteria but rather to institutionalized taken-for-granted norms (DiMaggio and Powell, 1983). Therefore, expanding on limited rationality in decision making, we argue that the specific political culture of the firms' environment is likely to mold firms' internationalization strategies. Furthermore, we extend the prior usage of the concepts of exploitation and exploration strategies from its original organizational learning perspective (see March, 1991) to a broader perspective that entails firms' internationalization strategies. In this regard, exploitation and exploration strategies find some parallel in market seeking and strategic asset-seeking strategies as used in international business research (e.g. Dunning, 1993; Makino et al., 2002). Firms pursuing a market-seeking strategy are essentially using or exploiting their resources and capabilities in further businesses and possibly overseas markets. Conversely, firms pursuing a strategic assetseeking strategy are essentially seeking to augment their resources and capabilities or are exploring new ones (see Barkema and Vermeulen, 1998; Kuemmerle, 1999; Vermeulen and Barkema, 2001).

\section{The Impact of Political Culture on Internationalization Strategy}

Extant research has recurrently noted how understanding cultural disparities among countries is essential for firms and individuals operating across borders (e.g. Douglas and Dubois, 1977; Firoz and Ramin, 2004; Li and Guisinger, 1991; Varner and Palmer, 
2005). To understand the role of culture in firms' key decisions, strategy research has examined how culture influences firms' strategies and leadership (Geletkanycz, 1998), efficiency (Palich and Gomez-Mejia, 1999), ownership structure (Erramilli, 1996; Hennart and Larimo, 1998; Kogut and Singh, 1988), mode of expansion (Brouthers and Brouthers, 2000), and the cross-national diffusion of technological and consumer innovations (Dwyer et al., 2005; Ganesh et al., 1997) among others. This research has shown that culture plays an important role in firms' decisions and performance. As Perlitz (1994: 55) stated, it is not the management techniques per se that determine firms' superior performance but rather that the firms' capabilities are themselves culturally 'predetermined'.

Political culture refers to the political orientations and attitudes toward the political system (Almond and Verba, 1963, 1989). It is 'the sum of the commonly perceived and deeply felt values and corresponding beliefs that permeate political and governmental activities in a given society' (Foster, 1982: 562). Political culture is a subset of the broader national culture. National culture encompasses many other elements of values, beliefs, behaviors, customs and artifacts, such as religion, folklore, gastronomy, social interaction, technology, institutions, and attitudes towards life, time, or the world (Hofstede, 1980, 2001). All of these factors provide the members of society with a 'framework' to cope with their immediate world and with one another as well as with more distant worlds and peoples.

Like national culture (Hambrick et al., 1998), political culture is prone to have a strong effect on individuals' perceptions, attitudes, and behaviors. Individuals within the same country are likely to have been socialized into a similar political culture that distinguishes them from individuals in other countries. Moreover, as we noted before, although not all individuals in a given nation can be assumed to carry the characteristics of an identical political culture, to think or vote alike on political matters or share a distinctive political perspective, on average, firms and their managers in each country are likely to share a larger similarity in values related to that country's political culture compared to individuals in a different country. Even if the individuals' political culture tendencies deviate from the national tendency, the nationality imprinting is not easily removed (Hambrick et al., 1998). In organizational contexts, as Hofstede (1985: 347) stated,'[o]rganizational value systems are strongly influenced by their national value systems and the interrelated values of their founders and top managements'.

The dimensions of political culture patriotism, nationalism, internationalism, and cosmopolitanism - are utilized to express people's broader dispositions towards their own and foreign countries (see Balabanis et al., 2001; Cannon and Yaprak, 2002). The conceptual model we have developed (see Figure 1) suggests that the political culture of firms' home country is likely to determine firms' dominant internationalization strategy. The impact of cultural variables on firms' knowledge acquisition, strategy, and performance has been the subject of extensive research in international management studies. Existing research has mostly suggested either a main or a moderating effect of culture on the selection of entry mode (e.g. Brouthers and Brouthers, 2000; Hennart and Park, 1993; Johanson and Vahlne, 1977; Kogut and Singh, 1988), knowledge transfer (e.g. Appleyard, 1996; Bhagat et al., 2002), attracting foreign direct investment (Head and Sorensen, 2005), and the performance of cross-border acquisitions (e.g. Morosini et al., 1998). However, this research has not focused specifically on the possible impact of political culture on firms' internationalization strategy, or other cross cultural management issues. On the left side of Figure 1, we depict the relationships between political culture 


\section{Political culture}

\section{Strategy $\longrightarrow$ Entry modes}

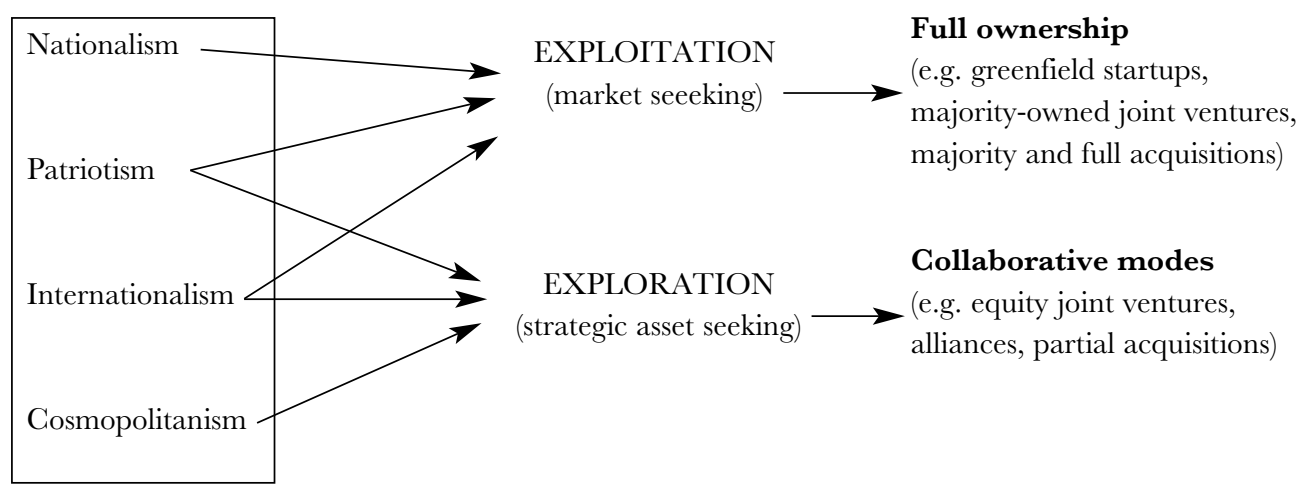

Figure 1 The conceptual model depicting the influence of political culture on the internationalization strategy of firms

and firms' internationalization strategy. On the right side, we introduce the linkages to foreign entry modes, which will be further developed in this article.

Nationalism A nationalist political culture is one in which the citizens believe that their own ethnic group, nation, culture, abilities, and products are superior to those of individuals and firms in other nations. Individuals in a nationalist culture base their assertions and beliefs on the idea that their nation is specific and unique, its products are better, its values and interests override all others from different nations and outside individuals, and that their nation should remain absolutely independent (Feshbach, 1990). Therefore, they tend to be prejudiced towards other nations and people and to restrict exchanges with out-group individuals. This leads to isolation and creation of a multitude of political and regulatory policies to restrict trade, foreign investment, immigration, foreign firms, and flows of intellectual property (Balabanis et al., 2001; Baugh and Yaprak, 1996; Kosterman and
Feshbach, 1989). Nationalism implies an attitude of cultural and ethnic superiority, involving the tendency to evaluate other cultures from one's own cultural perspective and to consider other cultures as 'inferior'.

Compared to those embedded in other political cultures (i.e. patriotic, internationalist, and cosmopolitan), firms embedded in nationalist political cultures are more likely to resort to exploitation strategies in the search for potentially better outcomes, where those outcomes are found in-house and developed following home-country standards. As previously mentioned, nationalist cultures are prejudiced against other cultures to the point of limiting trade or foreign investment. They tend to believe that what is produced with home country standards is superior and, therefore, firms embedded in nationalist cultures are likely to favor replication in foreign markets of what has proven to be good and have worked at home (i.e. what is thought to be superior). Alternatively, these firms may simply remain in the domestic market, avoiding foreign operations and international participation since they tend to 
consider other cultures inferior to their own. They are less likely to pursue exploration strategies and to look for opportunities beyond the current pool of markets as they regard foreign operations to be secondary to domestic ones. Furthermore, they consider access to new foreign knowledge or technology as secondary to the exploitation of current practices developed in the home country.

Proposition 1: Firms in nationalist political culture environments are more likely to pursue an exploitation strategy than are firms in other political culture environments.

Patriotism In a patriotic political culture, citizens tend to hold an overall preference for their own country's goods and services, but this preference is not as strong as it is in nationalist cultures. Although individuals in patriotic political culture would prefer to buffer their country from foreign goods, particularly if these were considered to create some form of social, cultural, and/or economic hazard, these individuals are acceptant of foreign producers (Balabanis et al., 2001). Although to a more moderate degree than nationalists, patriots also believe that their country, culture, and abilities are superior to others. They are still somewhat prejudiced against other nations and people, but they do not restrict exchanges and, therefore, tend to neither remain isolated nor raise a multitude of restrictive barriers to 'made abroad' products. However, we may expect patriots to be fairly parochial in their orientation to national or local communities and their offerings since patriots are driven by local habits, norms, and preferences in partial disregard for universal and objective standards. Nationalism and patriotism are significantly different: while the first entails feelings of national superiority compared to other nations, the latter encompasses emotional attachment to the nation and pride in one's national superiority (Figueiredo and Elkins, 2002).
In terms of internationalization strategies, firms embedded in a patriotic domestic culture are likely to pursue a combination of exploitation and exploration strategies. While the home environment is considered to be unique, patriots are also tolerant and, within some limits, acceptant of the eccentricities of foreign environments. Therefore, while firms embedded in a patriotic culture are more likely to encourage the exploitation of existing resources, capabilities, and knowledge that are based mostly on home country endowments and trajectories (Kogut, 1991), these firms are also likely to encourage, although to a lesser degree, some search outside the geographic boundaries for potential benefits. That is, firms embedded in a patriotic culture are likely to lean towards pursuing primarily an exploitation strategy because it contributes to the feeling of uniqueness and pride in national superiority of home country values, beliefs, and products. On the other hand, since patriots are tolerant of foreign cultures, firms in patriotic cultures may, in some instances, engage in some exploratory activity, possibly to the extent that it satisfies the need for exposure to potential modernization and experimentation from which they may upgrade their own capabilities. The outcome is essentially a home-centered strategy but one that is possibly well coordinated across borders by the headquarters, even if with subsidiaries reasonably well adapted to the host country's idiosyncrasies.

Proposition 2: Firms in patriotic political culture environments are more likely to pursue a combination of exploitation and exploration strategies, with a tendency leaning towards exploitation strategy, than are firms in other political culture environments.

Internationalism The concept of internationalism is used to represent the positive feelings of the citizens of a nation for other nations and people (Balabanis et al., 2001; Kosterman and Feshbach, 1989). Inter- 
nationalism reflects an orientation towards, and recognition of the coexistence of, a plurality of cultures, ideologies, and values. Internationalism further relies on the idea that local communities and individuals have specific preferences, desires, and tastes that require targeted tailoring and adaptation in a rationale illustrated by the expression 'when in Rome, do as the Romans do'. Hence, an internationalist attitude does not entail feelings or behaviors of superiority but of striving for absolute adaptation to the local communities' demands.

Organizations embedded in internationalist political cultures are likely to opt for a combination of exploration and exploitation strategie, although to a different degree than patriots. In particular, internationalists are likely to favor relatively more exploration strategies and experimentation with novel foreign products and services. Since internationalists tend to hold positive feelings towards other cultures and recognize the idiosyncrasies of the host environments, they may search for benefits associated with the exploration of what works best (i.e. the most adapted) in these environments. Simultaneously, they may recognize that the existing portfolio of products and/or services may be accepted in the host countries. Therefore, we expect internationalist cultures to favor the exploration of novel products and resource combinations that are in accord with their orientation towards a broad understanding of the world and, to a lesser degree, some exploitation of current capabilities and activities. Some degree of exploitation of current resources may be desirable to maintain the plurality of cultures, one of which is their own.

Proposition 3: Firms in internationalist political culture environments are more likely to pursue a combination of exploration and exploitation strategies, with a tendency leaning towards exploration strategy, than are firms in other political culture environments.
Cosmopolitanism Cosmopolitanism is derived from the Greek words kosmos, which means 'world' and 'order', and polis, which means 'fortified castle'. The expression 'cosmopolites' has been associated to 'citizen of the world' and to citizens of a nation that regard the whole world and mankind as more important than the idiosyncrasies of specific local communities or countries. Generally, 'cosmopolitan' is used to refer to people of a nation that are sophisticated and amenable to different cultures, products, ideas, and folklores, and not just those of their home country. Cosmopolitan political cultures are hybrids in that they incorporate the elements of the national community blended with traits found in other communities. In fact, cosmopolitan cultures tend to favor new experiences, food, music, exoticism, etc., that transcend the local culture (Holt, 1998) and to seek cultural diversity (Cannon and Yaprak, 2002). Merton (1957) referred to cosmopolitans as people who look beyond their localities and who are oriented towards the world outside the local community. Hence, in cosmopolitan cultures, individuals tend to see the world as their territory, without national prejudices or biases. However, a cosmopolitan is also typified as not being loyal to internal contexts (e.g. a job, a group or a nation), and as seeking references with external groups (Gouldner, 1957; Grimes and Berger, 1970).

Cosmopolitans tend to share a global cultural orientation and strive for a standard of excellence, quality, and rationality, regardless of where, for example, the products they consume come from. They also tend to avoid ethnocentric consumer behaviors (see Cannon and Yaprak, 2002). Thus, in cosmopolitan cultures, we expect individuals to neither be overly patriotic or conservative nor closed to foreign cultures. As Cannon and Yaprak (2002: 8) argued, 'they can transcend their local culture without abandoning it'. It is not surprising, then, that cosmopolitanism has been associated with the tendency 
to innovate (Helsen et al., 1993), partly because of a tendency to look broadly (explore non-locally) for answers or for better solutions (Cannon and Yaprak, 2002). This may be associated with an exploration strategy whereby individual decision makers in organizations do not focus only on the local perimeter but also scan the surrounding environment in search for global maximums. This is particularly interesting for international strategy research as it entails the potential to generate a competitive advantage through cosmopolitans' desire for novelty, excellence, quality, and excitement. This desire is accompanied by a broader exposure to alternatives since cosmopolitans are less likely to be 'satisfied by the traditionally accepted local standards that fall short of those available in the broader global market' (Cannon and Yaprak, 2002: 15).

We suggest that firms embedded in a cosmopolitan political culture are prone to follow a global strategy where investments across the world seek to maximize global exploration strategies and to respond accordingly to the opportunities detected. These firms are likely to have a more dynamic external orientation and continuously seek new opportunities and knowledge in foreign locations since a cosmopolitan orientation comes with seeking and even preferring new experiences beyond the local culture (Holt, 1998).

Proposition 4: Firms in cosmopolitan political culture environments are more likely to pursue an exploration strategy than are firms in other political culture environments.

We have suggested that the political culture of the firms' home country plays an important role on the type of internationalization strategy firms employ. In the next section, we extend our argument by drawing a link between firms' internationalization strategies and their actual modes of foreign market entry.

\section{Modes of Foreign Market Entry}

Firms may choose different modes of entry into foreign markets depending on the type of exploration-exploitation internationalization strategy they pursue (Andersen, 1997; Dunning, 1993; Johansson and Yip, 1994; Makino et al., 2002). As we discussed previously, the choice of strategy is likely to be at least partly determined by the dominant imprinting of the home country political culture on organizations. In this section, we discuss the impact of strategy on the selection of entry modes and provide brief examples of other organizational decisions such as those surrounding recruiting and procurement, as they are likely to be driven, even if indirectly, by the political culture in which firms are embedded.

The choice of foreign entry mode needs to be adapted to the firms' strategy (Dunning, 1993). In Table 1, we provide illustrative examples of how this adaptation may occur in terms of entry modes, the management of foreign operations (e.g. hiring of management personnel) and procurement (based on home or host country or globally), and other decisions for foreign operations that firms are more likely to adopt depending on their home base political culture and the corresponding degree of exploitation and exploration strategy pursued. Although it is beyond the scope of this article, it is possible to formulate a set of propositions for each stage of the firms' value chain to extend our understanding of the impact of political culture on internationalization strategy.

Firms pursuing an exploitation strategy in foreign markets are likely to seek foreign entry modes that guarantee a large degree of control over the foreign operations (Johansson and Yip, 1994; Makino et al., 2002). Exploitation strategies are better executed through the replication of what the firms know in other markets (see also Winter and Szulanski, 2001) and by avoiding unfamiliar risks (Stuart and Podolny, 1996). In 
332 International Fournal of Cross Cultural Management 5(3)

Table 1 Political culture and internationalization strategy

\begin{tabular}{|c|c|c|}
\hline $\begin{array}{l}\text { Dominant } \\
\text { political culture }\end{array}$ & $\begin{array}{l}\text { Dominant } \\
\text { strategy }\end{array}$ & Examples \\
\hline National & Exploitation & $\begin{array}{l}\text { - Mainly exports (direct and indirect) } \\
\text { - Greenfield (wholly owned sales subsidiary) } \\
\text { - Managers: expatriates } \\
\text { - Procurement: home-based }\end{array}$ \\
\hline Patriot & Exploitation & $\begin{array}{l}\text { - Exports } \\
\text { - Joint ventures with home partners } \\
\text { - Cross-border acquisitions (majority or full ownership) } \\
\text { - Managers: expatriates } \\
\text { - Procurement: home and host }\end{array}$ \\
\hline International & Exploration & $\begin{array}{l}\text { - Joint ventures with locals } \\
\text { - Acquisition of existing firms } \\
\text { - Managers: locals or expatriates } \\
\text { - Procurement: regional (e.g. EU, NAFTA) }\end{array}$ \\
\hline Cosmopolitan & Exploration & $\begin{array}{l}\text { - Equity joint ventures (all partners) } \\
\text { - Equity strategic alliances (all partners) } \\
\text { - Acquisitions (partial ownership) } \\
\text { - Managers: seeks worldwide } \\
\text { - Procurement: worldwide }\end{array}$ \\
\hline
\end{tabular}

particular, firms employing an exploitation strategy are likely to favor exports and wholly owned greenfield startups (Makino et al., 2002), particularly of subsidiaries for commercialization (i.e. sales subsidiaries). Wholly owned entries permit stronger control over the foreign operations and facilitate the replication of the home operations than alternative entry modes such as alliances or joint ventures (Woodcock et al., 1994). Furthermore, in these instances, it seems likely that foreign subsidiaries are managed by home country expatriates and procurement of inputs is essentially home country based.

On the other hand, firms pursuing a combination of exploitation and exploration strategies but leaning towards exploitation are likely to favor exports, but may also form partnerships, particularly with other home country firms or, perhaps, with a host country firm (see Makino and Beamish, 1999). In the latter case, it is reasonable to suggest that the preference will be for a majority equity ownership participation. Through foreign partnerships, these firms gain access to, and learn, foreign values, attitudes, and beliefs (Hamel et al., 1989; Inkpen, 1998; Levinson and Asahi, 1995). Nevertheless, the relative privilege for home-based partnerships is due to home market pressures and the need for legitimacy, which are perceived to be more important than responsiveness to local markets. We may also expect procurement activities in both the host and the home countries; however, the management style is likely to be imposed by expatriates who will tend to maintain a home-country-dominant 
orientation, which is consistent with the values of a patriotic culture.

Conversely, firms employing predominantly exploration strategies - which we predicted could be easily found in international political culture environments - are likely to be fairly eclectic in terms of the entry modes selected. In fact, a wide variety of entry modes into foreign markets may be appropriate for this strategy. For example, firms may enter equity joint ventures and strategic alliances with host country partners that provide local legitimacy and conformity to local conditions, but also seek complementary or pooled resources with home country partners. In this case, social and economic motivations are simultaneously and idiosyncratically considered. Furthermore, entry modes supported in equity operations are very probable, such as the partial acquisition of existing firms or greenfield investments in selected industries. The integration of foreign firms permits immediate access to foreign knowledge, technologies, and a labor force that carries local values, attitudes, and behaviors.

Finally, firms pursuing a more fully fledged exploration strategy in foreign markets are likely to employ entry modes that guarantee local embeddedness and access to local knowledge and learning (Dunning, 1993; Makino et al., 2002), which are likely to be attained through collaborative entry modes and shared equity modes in foreign subsidiaries (i.e. partial cross-border acquisitions and joint ventures) (Ferreira and Tallman, 2005). Furthermore, managers for foreign operations are likely to be sought worldwide and procurement activities are more likely to be driven by economic considerations than by the country origin of the inputs. Based on the above discussion, we advance two propositions:

Proposition 5a. Firms pursuing international exploitation strategies are more likely to enter foreign markets through entry modes that permit majority or full control over the foreign operations than through entry modes that do not permit majority or full control over the foreign operations.

Proposition 5b: Firms pursuing international exploration strategies are more likely to enter foreign markets through minority or equal ownership entry modes than through entry modes that permit majority or full control over the operations.

\section{Discussion and Conclusions}

Examining the impact of culture on firms' strategies is not an uncommon research endeavor in international management studies. Several studies in cross cultural and international management have already focused on the impact of cultural differences between home and host country on various strategic decisions, such as the choice among alternative entry modes, knowledge transfer, or the success of foreign operations (e.g. Bhagat et al., 2002; Kogut and Singh, 1988; Li and Guisinger, 1991;). However, a large majority of the extant research has been using Hofstede's (1980) cultural typology to set up conceptual and empirical distinctions. Yet, Hofstede's dimensions do not capture the broader political ideologies or permit an understanding of other aspects of culture, and present only a partial perspective that needs to be enriched with complementary 'culturally-based' constructs. Disaggregating the broad 'culture' term, we identified one cultural dimension, political culture, which has been overlooked in extant research but which is likely to be particularly useful for examining firms' internationalization strategies.

Our approach, which focuses on the role of the cultural environment in firms' choice of strategy, is consistent with traditional research on the influence of national culture on strategy and the idea that firms' strategies are determined within home country constraints and in partial disregard for an efficiency rationale (DiMaggio and Powell, 1983). Decision-makers are not necessarily 
fully rational and do not comprehensively use objective criteria (Simon, 1957) in evaluating home and host country characteristics. On the contrary, firms' strategic decisions are likely to be partly driven by the political culture in which firms are embedded. In particular, home country attitudes towards in-group (i.e. one's own nation) and outgroup (i.e. other nations) can, at least in part, determine the internationalization strategies pursued by firms. As suggested earlier, firms' strategic choices, as influenced by the political culture environment, may prevent them from entering new markets and exploring new opportunities. For instance, although expanding to new markets may be in the firms' best interest, firms in nationalist environments may choose exploitation-type strategies due to some hostility towards other nations, people, or products. These firms may lose the opportunity to augment their capabilities through an exploration strategy.

This paper also contributes to existing research by linking a specific dimension of culture to firms' strategies while drawing a connection between political culture environment and the choice of entry modes selected. To the best of our knowledge, this is the first piece of research to undertake this task and introduce political culture to the international strategy and cross cultural management research. This undertaking can provide a better understanding of a variety of decisions (e.g. location, hiring, procuring, or marketing decisions) given by firms expanding internationally.

Nevertheless, this article is not without limitations. We extended a concept that is essentially at the individual level (i.e. the political culture of each individual) to argue that we can distinguish countries and, hence, the individual decision-makers in organizations embedded in these countries on the basis of an average cultural tendency of the population. In other words, the assumption is that the belief and value systems of decisionmakers within organizations represent the cultural values of markets defined by nationality (Ronen and Shenkar, 1985). However, researchers need to proceed with caution when imputing to specific firms, or decisionmakers in these firms, any characteristic specific of a broader environment since not all individuals of the same nation are likely to carry the same cultural imprints to an equal degree. Arguably nationalities alone are insufficient proxies to fully capture the complexity entailed in cultural constructs.

Future research should examine the relationships proposed in this article by focusing on how home country political culture influences firms' strategies. These strategies may include those regarding the selection of strategic alliance partners, markets to enter, hiring, use of home country nationals or expatriates to manage foreign subsidiaries, organizational structures, and the degree of adaptation of products and services. Empirical work can be conducted through survey methodology using existing scales to measure nationalism, patriotism, internationalism, and cosmopolitanism as well as to capture the type of internationalization strategy (exploration and exploitation) firms pursue. Some instruments already exist to assess political culture (e.g. Ferguson, 1967; Kosterman and Feshbach, 1989; Levinson, 1957; Sullivan et al., 1999) and some work has already been done in the area of international marketing (see, for example, Balabanis et al., 2001) which may serve as a solid point of departure for the development of surveys. The primary data obtained through survey methodology can also be combined with secondary data on firms' modes of foreign expansion. To assess firms' propensity for engaging in exploration and/or exploitation strategies, existing surveys in strategic management research or other scales, such as those measuring novelty seeking and openness to experience (as a proxy for exploration strategy), may be useful.

Future research could also examine how 
individuals' and populations' political culture shifts over time as a result of, for example, exposure to foreign markets and agents. It is possible that higher worldwide economic integration may be favoring internationalist and cosmopolitan cultures while firms may continue to need to adjust their market offerings to satisfy a heterogeneous population (Levitt, 1983). In addition, following suggestions by Flango and Brumbaugh (1974), Balabanis et al. (2001), and Cannon and Yaprak (2002) that political culture dimensions are not in themselves entirely unidimensional, future research may consider a disaggregated view of each dimension to gain a better understanding of their impact on firm strategy and decision-making processes. For example, it is possible that nationalistic feelings are stronger when referring to foreign people or foreign firms than when referring to foreign products, values, norms, attitudes and behaviors.

Furthermore, although not explored in this paper, the magnitude of differences between the political cultures of the domestic and host environments (i.e. home-host country political culture distance) may affect the choice of entry mode. However, this effect is likely to be particularly pertinent in some instances which the traditional concept of cultural distance (e.g. Kogut and Singh, 1988) does not capture. For example, firms operating in a nationalist political culture may face more severe difficulties entering an equally nationalist environment than when entering an internationalist or a cosmopolitan environment because in these instances the cultural clash is likely to be more pronounced. Hence, future research can seek to understand how home-host country political culture distance affects the choice of foreign entry mode.

The arguments presented in this article have implications for practitioners. In particular, firms may partly buffer from the influence of home country political environment through their hiring decisions. Firms may assess potential job candidates, especially for the management level, on these cultural dimensions, and seek the best fit with the internationalization strategy aimed at. Firms can also search for job candidates who have a broader international experience and, thus, perhaps a more internationalist or cosmopolitan perspective towards economic and political matters. Individuals who have lived, studied, or worked outside their home nation will have been more exposed to other cultures, tend to speak foreign languages, and so forth. They are also more likely to have internalized cosmopolitan attitudes and behaviors. In addition, firms may hire expatriates both for home and host-based operations to overcome potential nationalist orientations.

In conclusion, the dominant political culture of the home country may play a role in shaping firms' internationalization strategies and the choice of entry mode through which strategy is executed. In this paper, we extended the analysis of the impact of culture on firms' strategies beyond the traditional utilization of culture to capture the political aspect of culture. Management and cross cultural research may benefit from this analysis as it emphasizes an important element of culture - one that relates to what one thinks about his or her nation and the attitudes and behaviors that follow this understanding. The extent to which political culture is a determinant of firms' managerial and strategic decisions warrants additional investigation.

\section{Acknowledgement}

A previous version of this paper was presented at the Western Academy of Management 2003. We acknowledge the partial support of the

Foundation for Science and Technology - MCT, Portugal (grant: SFRH/BD/880/2000). 


\section{References}

Almond, G. and Verba, S. (1963) The Civic Culture: Political Attitudes and Democracy in Five Nations. Boston, MA: Little, Brown.

Almond, G. and Verba, S. (1989) The Civic Culture Revisited. Newbury Park, CA: Sage.

Andersen, O. (1997) 'Internationalization and Market Entry Mode: A Review of Theories and Conceptual Framework', Management International Review 27 (2): 27-42.

Appleyard, M. (1996) 'How Does Knowledge Flow? Interfirm Patterns in the Semiconductor Industry', Strategic Management Fournal 17(winter): 137-54.

Balabanis, G., Diamantopoulos, A., Mueller, R.D. and Melewar, T.C. (2001) 'The Impact of Nationalism, Patriotism and Internationalism on Consumer Ethnocentric Tendencies', Fournal of International Business Studies 32(1): 157-75.

Barkema, H. and Vermeulen, F. (1998) 'International Acquisition through Start-up or Acquisition: A Learning Perspective', Academy of Management fournal 41 (1): 7-26.

Baugh, C., and Yaprak, A. (1996) 'Economic Rationalism: Conceptual and Empirical Development', Political Psychologist 17(4): 759-78.

Bhagat, R., Kedia, B., Harveston, P. and Triandis, H. (2002) 'Cultural Variations in the Cross-border Transfer of Organizational Knowledge: An Integrative Framework', Academy of Management Review 27(2): 204-21.

Brouthers, K. and Brouthers, L. (2000) 'Acquisition or Greenfield Start-up? Institutional, Cultural and Transaction Cost Influences', Strategic Management Fournal 21(1): 89-97.

Calof, J. and Beamish, P. (1994) 'The Right Attitude for International Success', Business Quarterly 59(1): 105-10.

Cannon, H. and Yaprak, A. (2002) 'Will the Real World Citizen Please Stand Up! The Many Faces of Cosmopolitan Consumer Behavior', Fournal of International Marketing 10(4): 30-52.

DiMaggio, P. and Powell, W. (1983) 'The Iron Cage Revisited: Institutional Isomorphism and Collective Rationality in Organizational Fields', American Sociological Review 48: 147-60.

Douglas, S. and Dubois, B. (1977) 'Looking at the Cultural Environment for International Marketing Opportunities', Columbia Fournal of World Business 12(4): 102-10.

Druckman, D. (1994) 'Nationalism, Patriotism, and Group Loyalty: A Social Psychological
Perspective', International Studies Quarterly 38(51): 43-68.

Dunning, J. (1993) Multinational Enterprises and the Global Economy. Boston, MA: Addison-Wesley Publishing Company.

Dwyer, S., Mesak, H. and Hsu, M. (2005) 'An Exploratory Examination of the Influence of National Culture on Cross-national Product Diffusion', Fournal of International Marketing 13(2): 1-27.

Erramilli, M. (1996) 'Nationality and Subsidiary Ownership Patterns in Multinational Corporations', Fournal of International Business Studies 27(2): 225-48.

Ferguson, L. (1967) 'Nationalism Scale III (1942)', in M. Shaw and J. Wright (eds) Scales for the Measurement of Attitudes. New York: McGraw Hill, 196-99.

Ferreira, M. and Tallman, S. (2005) 'Building and Leveraging Knowledge Capabilities through Cross-border Acquisitions', paper presented at the Academy of International Business meeting, Quebec, Canada.

Feshbach, S. (1990)'Psychology, Human Violence and the Search for Peace: Issues in Science and Social Values', Journal of Social Issues 46(1): 183-98.

Figueiredo, R. and Elkins, Z. (2002) 'Are Patriots Biglots? An Inquiry into the Vices of In-group Pride', working paper, University of California at Berkeley.

Firoz, N. and Ramin, T. (2004) 'Understanding Cultural Variables Is Critical to Success in International Business', International fournal of Management 21(3): 307-24.

Flango, V. and Brumbaugh, R. (1974) 'The Dimensionality of the Cosmopolitan-Local Construct', Administrative Science Quarterly 19(2): 198-210.

Foster, C.R. (1982) 'Political Culture and Regional Ethnic Minorities', The Fournal of Politics 44(2): 560-68.

Ganesh, J., Kumar, V. and Subramaniam, V. (1997) 'Learning Effect in Multinational Diffusion of Consumer Durables: An Exploratory Investigation', Fournal of the Academy of Marketing Science 25(3): 214-28.

Geletkanycz, M. (1998) 'The Salience of "Culture's Consequences": The Effects of Cultural Values on Top Executive Commitment to the Status Quo', Strategic Management fournal 18(8): 615-634.

Gouldner, A. (1957) 'Cosmopolitan and Locals: Toward an Analysis of Latent Social Roles I', Administrative Science Quarterly 2: 281-306.

Grimes, A. and Berger, P. (1970) 'Cosmopolitan- 
Local: Evaluation of the Construct', Administrative Science Quarterly 15(4): 407-16. Hambrick, D., Davison, S., Snell, S. and Snow, C. (1998) 'When Groups Consist of Multiple Nationalities: Toward an Understanding of the Implications', Organization Studies 19(2): 181-205.

Hamel, G., Doz, Y. and Prahalad, C. (1989) 'Collaborate with Your Competitors and Win', Harvard Business Review 67(1): 133-39.

Head, T. C. and Sorensen, P. F. (2005) 'Attracting Foreign Direct Investment: The Potential Role of National Culture', The Journal of American Academy of Business, Cambridge 6(1): 305-08

Helson, K., Jeddi, K. and DeSarbo, W. (1993) 'A New Approach to Country Segmentation Utilizing Multinational Diffusion Patterns', fournal of Marketing 57(4): 60-71.

Hennart, J-F. and Larimo, J. (1998) 'The Impact of Culture on the Strategy of the Multinational Enterprises: Does National Origin Affect Ownership Decisions?', Journal of International Business Studies 29(3): 515-39.

Hennart, J-F. and Park, Y. (1993) 'Greenfield vs. Acquisition: The Strategy of Japanese Investors in the United States', Management Science 39(9): 1054-70.

Hofstede, G. (1980) Culture Consequences, Beverly Hills, CA: Sage.

Hofstede, G. (1985) 'The Interaction Between National and Organizational Value Systems', Fournal of Management Studies 22(4): 347-57.

Hofstede, G. (1991) Cultures and Organizations: Software of the Mind. New York, McGraw-Hill.

Hofstede, G. (2001) Culture's Consequences: Comparing Values, Behaviors, Institutions, and Organizations across Nations. Beverly Hills, CA: Sage Publications.

Holt, D. (1998) 'Does Cultural Capital Structure American Consumption?', fournal of Consumer Research 25(June): 1-26.

Inkpen, A. (1998) 'Learning and Knowledge Acquisition through International Strategic Alliances', Academy of Management Executive 12(4): 69-80.

Johanson, J. and Vahlne, J-E. (1977) 'The Internationalization Process of the Firm: A Model of Knowledge Development and Increasing Foreign Market Commitment', Fournal of International Business Studies 8(1): 23-32.

Johansson, J. and Yip, G. (1994) 'Exploiting Globalization Potential: U.S. and Japanese Strategies', Strategic Management Fournal 15(8): 579-601.
Kogut, B. (1991) 'Country Capabilities and the Permeability of Borders', Strategic Management fournal 12: 33-47.

Kogut, B. and Singh, H. (1988) 'The Effect of National Culture on the Choice of Entry Mode', Fournal of International Business Studies 19(3): 411-32.

Kosterman, R. and Feshbach, S. (1989) 'Towards a Measure of Patriotic and Nationalistic Attitudes', Political Psychology 10(2): 257-74.

Koza, M. and Lewin, A. (1998) 'The Coevolution of Strategic Alliances', Organization Science 9(3): 255-64.

Kuemmerle, W. (1999) 'The Drivers of Foreign Direct Investment into Research and Development: An Empirical Investigation', Fournal of International Business Studies 30(1): $1-24$.

Levinson, D. (1957) 'Internationalism Nationalism Scale', in M. Shaw and J. Wright (eds) Scales for the Measurement of Attitudes, 201-3. New York: McGraw Hill.

Levinson, N. and Asahi, M. (1995) 'Crossnational Alliances and Interorganizational Learning', Organizational Dynamics 24(2): 50-63.

Levinthal, D. (1997) 'Adaptation on Rugged Landscapes', Management Science 43(7): 934-50.

Levinthal, D. and March, J. (1993) 'The Myopia of Learning', Strategic Management fournal 14(4): 45-62.

Levitt, T. (1983) 'The Globalization of Markets', Harvard Business Review May-June: 2-11.

Lewin, A., Long, C. and Carroll, T. (1999) 'The Coevolution of New Organizational Forms', Organization Science 10(5): 535-50.

Li, J. and Guisinger, S. (1991) 'Comparative Business Failures of Foreign-controlled Firms in the United States', Fournal of International Business Studies 22(2): 209-24.

Li, J., Lam, K. and Qian, G. (2001) 'Does Culture Affect Behavior and Performance of Firms? The Case of Joint Ventures in China', Journal of International Business Studies 32(1): 115-32.

Lord, R.G. and Foti, R.J. (1986) 'Schema Theories, Information Processing and Organizational Behavior', in H. Sims, Jr and D.A. Gioia (eds) The Thinking Organization: Dynamics of Organizational Social Cognition, pp. 20-48. San Francisco, CA: Jossey-Bass Inc.

Makino, S. and Beamish, P. (1999) 'Matching Strategy with Ownership Structure in Japanese Joint Ventures', Academy of Management Executive 13(4): 17-29. 
Makino, S. and Neupert, K. (2000) 'National Culture, Transaction Costs, and the Choice between Joint Venture and Wholly Owned Subsidiary', Fournal of International Business Studies 31(4): 705-14.

Makino, S., Lau, C-M. and Yeh, M-S. (2002) 'Asset-exploiting versus Asset-seeking: Implications for Location Choice of Foreign Direct Investment from Newly Industrialized Economies', Fournal of International Business Studies 33(3): 403-21.

March, J. (1991) 'Exploration and Exploitation in Organizational Learning', Organization Science 2(1): 71-87.

Melberg, H. (1996) 'About Confusing the Explanandum and the Explananda: Should Political Culture Include Behavioural Variables?' http://www.geocities.com/ hmerberg/papers/960926.htm, accessed 3 September 2004.

Merton, R. (1957) Social Theory and Social Structure. New York: Free Press.

Morosini, P., Shane, S. and Singh, H. (1998) 'National Cultural Distance and Cross-border Acquisition Performance', Fournal of International Business Studies 29(1): 137-58.

Nelson, R. and Winter, R. (1982) An Evolutionary Theory of Economic Change. Cambridge, MA: Belknap Harvard.

Palich, L. and Gomez-Mejia, L. (1999) 'A Theory of Global Strategy and Firm Efficiencies: Considering the Effects of Cultural Diversity', Fournal of Management 25(4): 587-607.

Parkhe, A. (1991) 'Interfirm Diversity, Organizational Learning, and Longevity in Global Strategic Alliances', fournal of International Business Studies 22(4): 579-601.

Perlitz, M. (1994) 'The Impact of Cultural Differences on Strategy Innovation', European Business fournal 6(2) 55-62.

Perlmutter, H. (1969) 'The Tortuous Evolution of the Multinational Corporation', Columbia Fournal of World Business Jan-Feb: 9-18.

Pothukuchi, V., Damanpour, F., Choi, J., Chen, C. and Park, S. (2002) 'National and Organizational Culture Differences and
International Joint Venture Performance', Fournal of International Business Studies 33(2): 243-66.

Ronen, S. and Shenkar, O. (1985) 'Clustering Countries on Attitudinal Dimensions: A Review and Synthesis', Academy of Management Review 10(3): 435-454.

Salk, J. and Brannen, M. (2000) 'National Culture, Networks, and Individual Influence in a Multinational Management Team', Academy of Management fournal 43(2): 191-203.

Simon, H. (1957) Models of Man: Social and Rational. New York: Wiley.

Stuart, T. and Podolny, J. (1996) 'Local Search and the Evolution of Technological Capabilities', Strategic Management Fournal 17: 21-36.

Sullivan, J., Fried, A., Theiss, M and Dietz, M. (1999) 'Patriotism Scale (1992)', in J.

Robinson, P. Shaver and L. Wrightsman (eds) Measures of Political Attitudes. Measures of Social Psychological Attitudes, vol. 2, pp. 553-62. New York: Academic Press.

Teegen, H. and Doh, J. (2002) 'U.S.-Mexican Alliance Negotiations: Impact of Culture on Authority, Trust, and Performance', Thunderbird International Business Review 44(6): 749-75.

Trompenaars, F. and Hampden-Turner, C. (1998) Riding the Waves of Culture. New York: McGraw-Hill.

Varner, I. and Palmer, T. (2005) 'Role of Cultural Self-knowledge in Successful Expatriation', Singapore Management Review 27(1): 1-26.

Vermeulen, F. and Barkema, H. (2001) 'Learning through Acquisitions', Academy of Management fournal 44(3): 457-76.

White, S. (1979) Political Culture and Soviet Politics. Macmillan, London.

Winter, S. and Szulanski, G. (2001) 'Replication as Strategy', Organization Science 12(6): 730-43.

Woodcock, C., Beamish, P. and Makino, S. (1994) 'Ownership-based Entry Mode Strategies and International Performance', Fournal of International Business Studies 25(2): 253-73. 
01_CCM 5_3 9/13/05 11:31 AM Page 340

340 International Fournal of Cross Cultural Management 5(3) 